\title{
DIVERSIFIKASI PRODUK USAHA AYAM GORENG JENG SRI DI PLASA, KUTA, BADUNG, BALI
}

\author{
I Wayan Ruspendi Junaedi ${ }^{1}$, Eko Sulistyo ${ }^{2}$, Putu Aristya Adi Wasita ${ }^{3}$, Gede Nyoman \\ Wiratanaya $^{4}$ \\ ${ }^{1}$ Program Studi Manajemen Fakultas Ekonomika dan Humaniora Universitas Dhyana Pura \\ ${ }^{2}$ Program Studi Manajemen Fakultas Ekonomika dan Humaniora Universitas Dhyana Pura \\ ${ }^{3}$ Program Studi Akuntansi Fakultas Ekonomika dan Humaniora Universitas Dhyana Pura \\ ${ }^{4}$ Program Studi Manajemen Fakultas Ekonomika dan Humaniora Universitas Dhyana Pura
}

ruspendijunaedi@undhirabali.ac.id, ekosulistyo@undhirabali.ac.id, aris@undhirabali.ac.id, yayakwiratanaya@gmail.com

\begin{abstract}
Abstrak
Ayam Goreng, Jeng Sri terletak Jl. Majapahit no. 37, Desa Plasa, Kecamatan Kuta, Provinsi Bali. Dari hasil pengamatan pada kelompok ini diketahui bahwa belum menerapkan manajemen pengelolaan dan pemasaran yang professional serta hanya satu produk yaitu ayam goreng. Pada pemasaran serta pelaporan keuangan belum menggunakan teknologi secara maksimal. Dalam proses pembuatan serta penyajian Ayam Goreng, Jeng Sri kurang memperhatikan etika dan perilaku konsumen serta belum ada ide diferensiasi produk. Akibatnya, kelompok mitra belum berkembang secara maksimal sehingga omzet penjualannya relatif masih kecil. Berdasarkan hasil sosialisasi tentang program PKM ini, maka kelompok ini menginginkan agar tim dari Universitas Dhyana Pura bersedia membantu mereka unutk mentransfer Ipteks dalam rangka mengatasi masalah yang dihadapi selama ini dan memberikan diversifikasi produk baru.

Dalam menyelesaikan masalah di atas, maka solusinya adalah memberikan pendampingan, penyuluhan, dan pelatihan tentang menajemen pengelolaan dan pemasaran, penggunaan teknologi, laporan keuangan serta diversifikasi produk seperti membuat pentol Bakso, Mie Ayam dan Pork Baley. Target program ini bersifat aktual untuk meningkatkan pengetahuan dan wawasan kelompok usaha Ayam Goreng, Jeng Sri semakin lebih baik. Dalam rangka keberlanjutan program PKM ini, maka tim melakukan evaluasi serta monitoring secara berkala terhadap kelompok mitra tersebut. Sehingga omzet penjualan semakin meningkat, dan memberikan inspirasi kepada masyarakat untuk berwirausaha sehingga meningkatkan kesejahteraan masyarakat di sekitarnya.
\end{abstract}

Kata Kunci : Ayam Goreng Jeng Sri, Diversifikasi, Pemasaran, Pendampingan, dan Teknologi.

\section{PENDAHULUAN}

\subsection{Analisis Situasi}

Kendati Ayam Goreng sudah lama dikenal oleh masyarakat, namun Ayam Goreng, Jeng Sri merupakan varian baru yang berbeda dengan Ayam Goreng pada umumnya. Keunikan Ayam Goreng, Jeng Sri terletak pada rasa, bentuk, dan racikan bumbunya yang lezat sehingga menggugah selera konsumen. Ayam Goreng, Jeng
Sri memiliki cita rasa yang tinggi sesuai level kepedasannya. Industri rumah tangga Ayam Goreng, Jeng Sri ini terletak di Desa Plaza, Kecamatan Kuta, Kabupaten Badung, Provinsi Bali. Bentuk Ayam Goreng, Jeng Sri yang sudah siap dikomsumsi seperti terlihat pada gambar di bawah ini. 

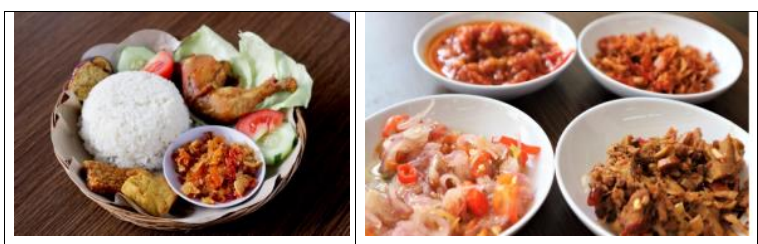

Gambar 1.1 Contoh Ayam Goreng, Jeng Sri Yang Siap Saji

Usaha Ayam Goreng, Jeng Sri di Desa Plaza, Kecamatan Kuta, Kabupaten Badung, Provinsi Bali diketuai oleh $\mathrm{Ni}$ Wayan Sri Wahyuningsih alias Sri. Kelompok usaha Ayam Goreng, Jeng Sri sudah berdiri sekitar 1 tahun lalu yang beranggotakan 3 orang. Usaha ini masih mengerjakan secara konvensional serta belum menerapkan manajemen pengelolaan dan pemasaran yang professional selama ini. Proses pembuatan Ayam Goreng, Jeng Sri diawali dengan pembelian daging ayam, kemudian di ungkep (dimasak) untuk mendapatkan rasa gurihnya. Selain itu, untuk mengungkepkan menggunakan cabe, bawang merah, saus, kecap, serta beberapa bumbu pelengkap lainnya. Bahan baku Ayam Goreng menggunakan Ayam dan Bumbu. Proses pembuatan Ayam Goreng, Jeng Sri masih menggunakan alat sederhana serta kurang memperhatikan hygeinesitas seperti yang terlihat pada gambar di bawah ini.
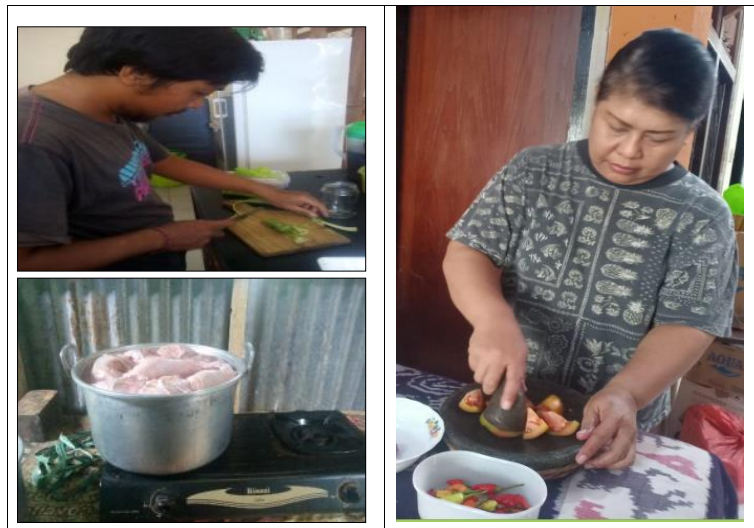

Gambar 1.2 Proses pembuatan Ayam Goreng, Jeng Sri tanpa sarung tangan

Berdasarkan hasil wawancara dengan Ibu Ni Wayan Sri Wahyuningsih dijelaskan bahwa pada awal membuka usaha Ayam Goreng, Jeng Sri rata-rata omzet penjualan sekitar Rp. 3.000.000/bulan. Harga satu paket Ayam Goreng, Jeng Sri Rp.15.000/porsi. Omzet penjualan relatif sangat kecil, sehingga margin keuntungan sebesar 10\% yaitu sekitar Rp.300.000/bulan. Hasil penjualan selama sebulan terakhir mengalami peningkatan sedikit di mana kelompok Ni Wayan Sri Wahyuningsih sudah mulai menggunakan daging ayam $20 \mathrm{~kg} / \mathrm{bulan}$, dan cabe $20 \mathrm{~kg} / \mathrm{bulan}$. Rata-rata omzet penjualan untuk kelompok $\mathrm{Ni}$ Wayan Sri Wahyuningsih pada saat ini mengalami peningkatan sekitar Rp.6.000.000/bulan atau Rp.72.000.000/tahun. Kendati demikian, omzet penjualan Ayam Goreng, Jeng Sri ini relatif masih kecil dibandingkan dengan peluang usaha yang ingin dicapai oleh mitra tersebut.

Proses pembuatan Ayam Goreng, Jeng Sri

membutuhkan waktu sekitar 10-15 menit/porsinya. Waktu yang cukup lama ini sangat mengganggu kenyamanan konsumen. Kepuasaan pelanggan menjadi prioritas utama karena semakin tinggi kepuasaan konsumen terhadap pelayanan perusahaan, maka semakin banyak konsumen yang loyal (Primayani \& Reonningrat, 2015: 157). Dengan memberikan kepuasan dan pelayanan yang maksimal kepada konsumen, maka semakin meningkatkan omzet penjualan Ayam Goreng, Jeng Sri tersebut.

Kendala yang dihadapi oleh kelompok usaha Ayam Goreng, Jeng Sri selama ini adalah belum menggunakan teknologi tepat guna secara maksimal, manajemen pengelolaan dan pemasaran yang kurang profesional, serta penyajiannya masih bersifat rumahan. Sumber daya manusia yang profesional merupakan salah satu kunci untuk meningkatkan kinerja dalam industri rumah tangga seperti usaha Ayam Goreng, Jeng Sri ini (Leovani, 2016). Omzet penjualan yang relatif kecil disebabkan tidak ada transfer teknologi yang optimal (Hapsari dan Prakoso, 2016). Akibatnya, setiap porsi Ayam Goreng, Jeng Sri membutuhkan waktu yang cukup lama.

Potensi pengembangan usaha Ayam Goreng, Jeng Sri di daerah ini sangat besar. Letak lokasi kelompok mitra ini sangat strategis karena kawasan padat penduduk, terdapat SD-SMP, serta jalur menuju pantai Kuta. Menurut Gunawan dan Suprapti (2015: 75) bahwa faktor demografi dapat mempengaruhi tingkah laku konsumen pada suatu produk, begitu pula pada sikap dan kesediaan konsumen untuk membayar. Hal ini sejalan dengan pendapat J. Barsky and L. Nash (Andimarjoko dan Wiharto, 2014: 38) menyatakan bahwa understanding customers emotional responses to a product or service in crucial for service businesses these responses affect customers' purchase decisions.

Lokasi yang sangat strategis ini menunjukkan adanya potensi pasar yang terbuka lebar jika dikelola secara maksimal. Ada tiga faktor yang mempengaruhi sikap terhadap lingkungan, yaitu faktor kepribadian, demografis, dan sistem nilai (Djumaty, 2015). Ketiga faktor 
sangat mempengaruhi pengembangan usaha Ayam Goreng, Jeng Sri pada daerah ini. Akan tetapi, kelompok usaha ini hanya mampu melayani pesanan masyarakat dengan jumlah terbatas selama ini. Apabila ada acara ulang tahun atau event yang sifatnya mendadak maka terpaksa ditolak karena keterbatasan Sumber Daya Manusia (SDM), modal, dan alat yang masih sederhana tersebut.

$$
\text { Apabila kelompok UKM ini }
$$
menggunakan teknologi tepat guna secara maksimal dan menerapkan manajemen pengelolaan serta pemasaran secara profesional maka dapat meningkatkan omzet penjualan Ayam Goreng, Jeng Sri sekitar 2-3 kali lipat. Berdasarkan analisis ini maka dapat diprediksi bahwa omzet penjualan kelompok Ni Wayan Sri Wahyuningsih bisa mencapai Rp.20.000.000/bulan atau Rp.240.000.000/tahun. Apabila tidak ada solusi penyelesaiannya, maka kelompok usaha Ayam Goreng, Jeng Sri ini memiliki potensi kehilangan pendapatan sekitar Rp12.000.000-15.000.000/bulan. Oleh sebab itu, solusi untuk mengatasi masalah kelompok usaha ini yaitu memberikan pendampingan, penyuluhan, dan pelatihan tentang menajemen, pemasaran, dan penggunaan teknologi tepat guna, serta menyajikan Ayam Goreng, Jeng Sri secara modern, sehingga memberikan pelayanan yang maksimal kepada setiap konsumen.

Dengan adanya industri rumah tangga Ayam Goreng, Jeng Sri di Desa Plaza maka masyarakat dapat mengurangi mengkonsumsi Daging Sapi atau daging Babi. Peralihan pola konsumsi ke jenis lain dapat menambahkan keberlanjutan kehidupan manusia di dunia ini (Atmoko dan Among, 2016). Apalagi akhir-akhir ini anggota masyarakat sangat sulit mendapatkan daging serta harganya semakin tinggi. Selain itu, usaha Ayam Goreng, Jeng Sri berdampak positif terhadap peningkatan ekonomi kelompok usaha ini serta masyarakat di sekitarnya. Oleh sebab itu, kelompok usaha ini menginginkan agar mendapatkan pendampingan dan pelatihan secara khusus agar mereka mampu menggunakan teknologi tepat guna secara maksimal, menerapkan manajemen usaha yang profesional, memberikan kepuasaan kepada konsumen, serta mampu menjaga kuantitas dan kualitas produk Ayam Goreng, Jeng Sri tersebut.

\subsection{Permasalahan Mitra}

Permasalahan pada kelompok industri rumah tangga Ayam Goreng, Jeng Sri di atas, yaitu:

1.2.1 Identifikasi permasalahan yang
dihadapi

Berdasarkan hasil wawancara serta pengamatan terhadap kelompok mitra ini terdapat beberapa masalah yang dihadapi, yaitu:

1. Masalah produksi. Kelompok mitra ini masih sangat minim pengalaman, sehingga kuantitas dan kualitas produksi Ayam Goreng, Jeng Sri kurang memuaskan konsumen. Kelompok mitra ini belum menggunakan teknologi tepat guna dalam membuat ayam goreng, pengirisan bawang, tempat memasak, dan penggilingan cabe, sehingga proses pembuatan Ayam Goreng, Jeng Sri membutuhkan waktu yang cukup lama. Oleh sebab itu, kelompok mitra ini belum mampu melayani permintaan konsumen dalam jumlah banyak.

2. Masalah manajemen. Proses pembuatan dan penyajiannya Ayam Goreng, Jeng Sri masih bersifat rumahan. Sumber daya manusia yang kurang kompeten dalam memberikan pelayanan kepada konsumen. Jumlah anggota kelompok Ni Wayan Sri Wahyuningsih hanya 3 orang. Manajemen pengelolaan serta pembuatan buku laporan keuangan masih bersifat sederhana karena belum menggunakan komputer, sehingga laporan keuangannya kurang valid, kurang rapi, dan kurang transparan.

3. Masalah pemasaran. Dalam pemasaran produk Ayam Goreng, Jeng Sri selama ini menggunakan spanduk di depan toko dan promosi dari mulut ke mulut, sehingga hanya sedikit konsumen yang mengetahuinya. Dengan manajemen pemasaran yang kurang baik, maka pangsa pasar yang digarap belum memenuhi standard yang maksimal sehingga omzet penjualannya sedikit.

\subsubsection{Permasalahan perioritas yang harus ditangani}

Berdasarkan permasalahan di atas, maka beberapa hal yang menjadi prioritas utama untuk penyelesaiannya, yaitu:

1. Pendampingan, penyuluhan, dan pelatihan dalam meningkat produksi Ayam Goreng, Jeng Sri dengan menggunakan teknologi. Penggunaan teknologi tepat guna dalam penggilingan cabe, dan pengirisan bawang. Dengan penggunaan teknologi maka kualitas Ayam Goreng, Jeng Sri meningkat dan waktu yang dibutuhkan sangat sedikit.

2. Pendampingan, penyuluhan, dan pelatihan dalam manajemen pengelolaan. Pendampingan ini dimulai dari proses penyediaan bahan baku, penyuluhan dalam menyajikan Ayam Goreng Jeng Sri, agar 
tetap menjaga hygenis serta memberikan pelayanan yang maksimal kepada konsumen dengan memperhatikan budaya dan etika kerja, serta pelatihan membuat buku laporan keuangan dengan menggunakan komputer. Menurut Wijayanti dan Insani (2016: 297) bahwa keberadaan perusahaan ditandai dengan adanya inovasi produk, pasar, teknologi, dan sikap proaktif. Penerapan manajemen yang baik maka dapat meningkatkan kuantitas dan kualitas Ayam Goreng, Jeng Sri pada kelompok ini. Dengan demikian, manajemen ini dapat mendukung pengembangan calon wirausaha baru di Provinsi Bali pada khususnya dan Indonesia pada umumnya.

3. Pendampingan, penyuluhan, dan pelatihan dalam pemasaran. Pemasaran sangat penting dilakukan oleh setiap pelaku usaha terlebih terhadap produk Ayam Goreng, Jeng Sri ini yang merupakan varian baru bahan makanan. Oleh sebab itu, tim memberikan pendampingan dan pelatihan dalam membuat promosi produk melalui internet (media sosial) dan media cetak koran. Dalam dunia bisnis seperti usaha Ayam Goreng, Jeng Sri membutuhkan internet untuk mempromosikan produknya dan menjadi ladang perburuan emas (gold rush) yang berkembang saat ini (Atmanto, 2017).

Tabel 1.1 Masalah dan Solusi Terhadap Mitra

\begin{tabular}{|c|l|l|l|}
\hline No & \multicolumn{1}{|c|}{ Masalah } & \multicolumn{1}{|c|}{ Solusi } & \multicolumn{1}{c|}{ Target Luaran } \\
\hline 1 & Produksi & $\begin{array}{l}\text { Pelatihan dan } \\
\text { pendampingan } \\
\text { penggunaan teknologi } \\
\text { tepat guna serta } \\
\text { membantu pembelian 1 } \\
\text { set mesin penggilingan } \\
\text { cabe (Mixer) }\end{array}$ & $\begin{array}{l}\text { Mempercepat proses produksi serta } \\
\text { meningkatkan kualitas dan kuantitas } \\
\text { Ayam, cabe, dan bawang yang } \\
\text { digunakan untuk campuran Ayam } \\
\text { Goreng, Jeng Sri tersebut. }\end{array}$ \\
\hline 2 & Manajemen & $\begin{array}{l}\text { Pelatihan dan } \\
\text { pendampingan } \\
\text { manajemen pengelolaan } \\
\text { yang profesional pada } \\
\text { kelompok mitra }\end{array}$ & $\begin{array}{l}\text { Memberikan kepuasaan kepada } \\
\text { konsumen sesuai etika dan budaya } \\
\text { kerja yang profesional serta membuat } \\
\text { laporan keuangan secara lengkap dan } \\
\text { transparan dengan menggunakan } \\
\text { teknologi . }\end{array}$ \\
\hline 3 & Pemasaran & $\begin{array}{l}\text { Pelatihan pemasaran di } \\
\text { internet dan media } \\
\text { cetak, media social spt } \\
\text { FB, IG dan Line. } \\
\text { Disamping itu juga } \\
\text { memasukan ayam } \\
\text { goreng Jeng sri ke } \\
\text { aplikasi go food dan } \\
\text { Grab dan pembelian 1 } \\
\text { alat yang dipasang di } \\
\text { warung untuk fasilitas } \\
\text { wifi para konsumen. }\end{array}$ & $\begin{array}{l}\text { Masyarakat semakin mengetahui } \\
\text { produk Ayam Goreng, Jeng Sri dan } \\
\text { omzet penjualan meningkat setiap } \\
\text { tahunnya. Konsumen bisa } \\
\text { menongkrong sambil belanja disana } \\
\text { karena tersedia fasilitas wifi. }\end{array}$ \\
\hline
\end{tabular}

\section{SOLUSI DAN TARGET LUARAN}

\subsection{Solusi}

Industri rumah tangga Ayam Goreng, Jeng Sri kelompok Ni Wayan Sri Wahyuningsih di Desa Plaza ternyata belum berkembang secara maksimal karena ada beberapa masalah yang dihadapi selama ini. Berdasarkan hasil pengamatan dan keluhan serta keinginan dari kelompok usaha Ayam Goreng, Jeng Sri ini, maka beberapa solusi penyelesaian masalahnya, yaitu:

1. Memberi pendampingan, penyuluhan, dan pelatihan kepada wirausaha baru ini agar mampu menggunakan teknologi tepat guna dalam penggilingan cabe, dan pengirisan bawang. Oleh sebab itu, dibantu untuk pembelian penggilingan cabe satu set pada kelompok mitra. Pemanfaatan teknologi tepat guna dapat meningkatkan produksi Ayam Goreng Jeng Sri, waktu yang dibutuhkan semakin singkat, serta memberikan pelayanan yang cepat kepada konsumen, sehingga omzet penjualan meningkat setiap tahunnya.

2. Memberikan pendampingan, penyuluhan, dan pelatihan manajemen yang profesional. Setiap kelompok diberi pelatihan tentang perilaku melayani konsumen sesuai budaya dan etika masyarakat. Dalam proses pembuatan dan penyajiannya harus menjaga higenisitas serta kebersihan lingkungan kerja. Dengan memiliki sumber daya manusia yang profesional maka konsumen terpuaskan, sehingga semakin sering mengkonsumsi Ayam Goreng, Jeng Sri tersebut. Tujuan pelatihan ini ini adalah untuk meningkatkan pengetahuan untuk memuaskan konsumen.

3. Memberikan pendampingan, penyuluhan, dan pelatihan dalam pemasaran produk Ayam Goreng, Jeng Sri secara benar dengan menggunakan internet dan media cetak dan media social (FB, IG dan Line) serta memasukan Ayam Goreng Jeng Sri ke sistem aplikasi Go Food (atau Go Grab) serta membelikan fasilitas wifi untuk warung. Pemasaran menjadi kunci utama dalam menjual produk Ayam Goreng, Jeng Sri. Dengan promosi yang benar maka dapat meningkatkan omzet penjualan serta mengembangkan usaha ini demi kesejahteraan anggota kelompok usaha ini maupun masyarakat di sekitarnya.

\subsection{Target Luaran}

Program kemitraan kepada masyarakat industri rumah tangga Ayam Goreng, Jeng Sri terhadap kelompok Ni Wayan Sri Wahyuningsih di Desa Plaza, Kabupaten Badung; memiliki target luaran sebagaimana tertuang pada tabel di bawah ini. 
Tabel 2.1 Tabel Target PKM

\begin{tabular}{|c|l|l|l|}
\hline No & \multicolumn{1}{|c|}{ Uraian } & Target Kelompok Mitra & \multicolumn{1}{c|}{ Keterangan } \\
\hline 1 & $\begin{array}{l}\text { Pelatihan dan } \\
\text { pemberian bantuan } \\
\text { teknologi tepat guna } \\
\text { untuk penggilingan } \\
\text { Cabe }\end{array}$ & $\begin{array}{l}\text { Kelompok mitra } \\
\text { mendapatkan pelatihan } \\
\text { dan pendampingan } \\
\text { penggunaan teknologi } \\
\text { serta bantuan 1 set Mixer }\end{array}$ & $\begin{array}{l}\text { Mesin mixer berfungsi } \\
\text { untuk mempercepat } \\
\text { produksi serta } \\
\text { meningkatkan kualitas } \\
\text { Ayam Goreng yang } \\
\text { digunakan untuk } \\
\text { campuran Bumbu }\end{array}$ \\
\hline 2 & $\begin{array}{l}\text { Pendampingan dan } \\
\text { pelatihan manajemen } \\
\text { pengelolaan }\end{array}$ & $\begin{array}{l}\text { Kelompok mitra } \\
\text { mendapatkan pelatihan } \\
\text { dan pendampingan dalam } \\
\text { penyajian Ayam Goreng, } \\
\text { Jeng Sri }\end{array}$ & $\begin{array}{l}\text { Memberikan pelayanan } \\
\text { yang maksimal kepada } \\
\text { konsumen sesuai etika } \\
\text { dan budaya serta } \\
\text { meningkatkan kepuasan } \\
\text { konsumen }\end{array}$ \\
\hline 3 & $\begin{array}{l}\text { Pendampingan dan } \\
\text { pelatihan pemasaran } \\
\text { produk melalui } \\
\text { internet dan media } \\
\text { cetak serta media } \\
\text { social. }\end{array}$ & $\begin{array}{l}\text { Kelompok mitra } \\
\text { mendapatkan pelatihan } \\
\text { pemasaran produk melalui } \\
\text { internet dan media cetak, } \\
\text { dan memasukan Ayam } \\
\text { goreng Jeng Sri ke } \\
\text { aplikasi Go Jek dan Grab }\end{array}$ & $\begin{array}{l}\text { Pemasaran melalui } \\
\text { internet dan media cetak } \\
\text { dan media social , Go Jek } \\
\text { serta Grab dapat } \\
\text { meningkatkan jumlah } \\
\text { konsumen dan omzet } \\
\text { penjualan Ayam Goreng } \\
\text { Jeng Sri }\end{array}$ \\
\hline
\end{tabular}

\section{METODE PELAKSANAAN}

\subsection{Metode Pelaksanaan}

Lokasi Program Kemitraan Masyarakat ini dilaksanakan pada industri rumah tangga Ayam Goreng Jeng Sri kelompok Ni Wayan Sri Wahyuningsih di Desa Plaza, Kabupaten Badung, Provinsi Bali. Program pengabdian kepada masyarakat terhadap kelompok usaha ini merupakan sebuah program yang bersifat aktual dalam rangka peningkatan pengetahuan serta wawasan kelompok usaha Ayam Goreng Jeng Sri tersebut. Oleh sebab itu, beberapa langkah untuk mengatasi permasalahan yang dihadapi oleh mitra ini, yaitu:

1. Permasalahan dalam bidang produksi. Memberikan pendampingan dan pelatihan penggunaan teknologi tepat guna (Mixer) yaitu Penggilingan cabe, sehingga kuantitas dan kualitas produk meningkat.

2. Permasalahan dalam bidang manajemen. Memberikan pendampingan dan pelatihan dalam pengembangan usaha Ayam Goreng Jeng Sri serta pemahaman tentang etika dan budaya konsumen. Dengan menajemen yang profesional dan pemahaman etika serta budaya, maka dapat meningkatkan minat konsumsi konsumen terhadap Ayam Goreng Jeng Sri tersebut. Membuat laporan keuangan sederhana, sehingga biaya produksi, hasil penjualan, dan keuntungan dapat diaudit secara cepat dan transparan.

3. Permasalahan dalam bidang pemasaran. Memberikan pendampingan dan pelatihan dalam memasarkan Ayam Goreng Jeng Sri secara benar dengan menggunakan internet, media cetak, Media social (FB, IG, Line) dan sistem aplikasi Go Jek dan Grab. Disamping itu juga membelikan fasilitas Wifi di warung bagi para konsumen yang berbelanja sehingga bisa betah di sana dan meng up date Menu liwat aplikasi. Dengan penggunaan metode pemasaran seperti ini dapat mempercepat anggota masyarakat mengetahui lokasi dan keistimewaan dari produk yang dipasarkan, sehingga jumlah konsumen semakin banyak dan omzet penjualan pun pasti meningkat.

Dalam mencapai tujuan program ini, maka rancangan yang sesuai untuk digunakan adalah Rural Rapid Appraisal dan Participant Rapid Appraisal (RRA dan PRA). Pelaksanaan program ini tetap mengacu pada pola sinergisitas antara kelompok mitra, tenaga pakar dan praktisi dari Universitas Dhyana Pura. Oleh sebab itu, program pengabdian kepada masyarakat ini diharapkan terciptanya iklim kerja sama yang kolaboratif serta demokratis dalam dimensi mutualis antara dunia perguruan tinggi dengan kelompok usaha Ayam Goreng Jeng Sri maupun masyarakat di sekitarnya.

Kehadiran Ayam Goreng Jeng Sri dapat dijadikan sebagai salah satu sumber bahan daging. Kelompok usaha Ayam Goreng Jeng Sri ini dapat memberikan kontribusi positif bagi generasi muda untuk menjadi wirausaha baru dalam berbagai bidang kegiatan usaha, sehingga tercipta wirausaha muda yang semakin banyak di Desa Plaza. Berdasarkan uraian di atas, maka program ini merupakan sebuah langkah inovatif dan produktif yang sejalan dengan Tri Dharma perguruan tinggi yaitu pengabdian kepada masyarakat. Dengan demikian, PKM ini bermanfaat untuk meningkatkan kesejahteraan masyarakat di sekitar Kecamatan Kuta.

\subsection{Pelaksanaan Kegiatan}

Kegiatan program kemitraan kepada masyarakat kelompok usaha Ayam Goreng, Jeng Sri dilakukan dengan beberapa tahap, yaitu:

1. Kegiatan sosialisasi. Kegiatan sosialisasi dilakukan oleh tim pengabdian kepada masyarakat dari Undhira. Kegiatan sosialisasi dilaksanakan secara klasikal dengan menghadirkan peserta dalam suasana "kelas belajar". Target awal sosialisasi ini adalah setiap kelompok mendapatkan pemahaman tentang program ini, sehingga mereka berkeinginan menerima program ini. 


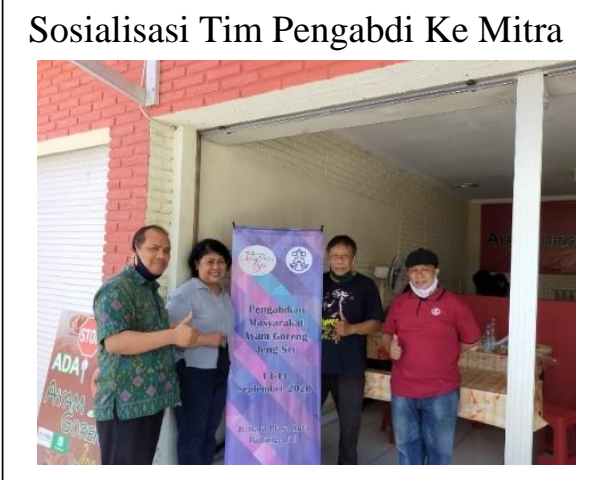

2. Kegiatan pelatihan penggunaan teknologi. Setiap kelompok mitra mendapatkan bantuan alat Blender dan Penggilingan Daging, kemudian dilatih oleh tim dan pakar dari Undhira tentang cara penyajian makanan tersebut. Setiap kelompok dilatih sampai bisa serta dievaluasi. Disamping itu juga di ajarkan membuat Mie ayam dan bakso sebagai diversifikasi produk.

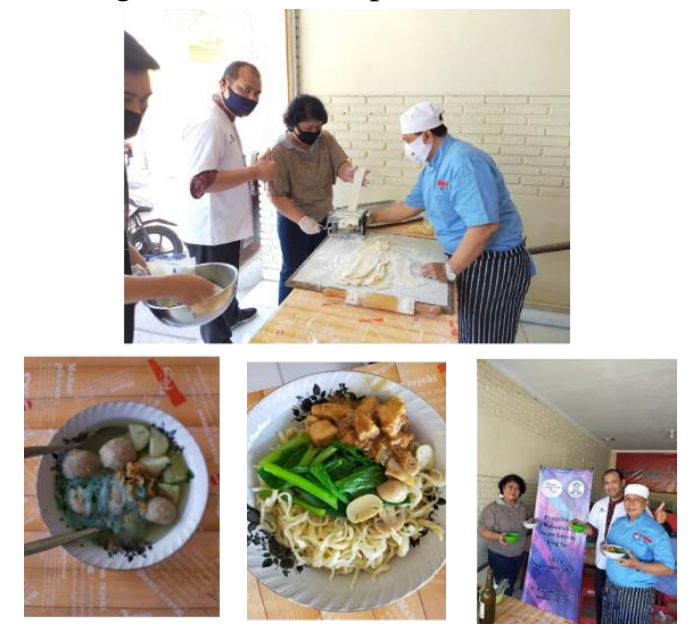

Gambar 1.3. Pelatihan Produksi Membuat Bakso dan Mie Ayam (Diversifikasi Produk)

3. Kegiatan pelatihan manajemen. Kegiatan pelatihan dilakukan oleh tim dan tenaga pakar dari Undhira. Kegiatan pelatihan ini bertujuan untuk menerapkan manajemen yang profesional serta memperhatikan etika dan perilaku konsumen pada saat menyajikan produk Ayam Goreng Jeng Sri ini. Setiap kelompok dilatih untuk menggunakan Blender dan Penggilingan daging sehingga lebih cepat dalam penggilingan bumbu yang akhirnya cepat menyajikan makanan ayam goreng Jeng Sri, disamping itu juga dalam membuat laporan keuangan juga dibantu, sehingga datanya valid dan transparan.

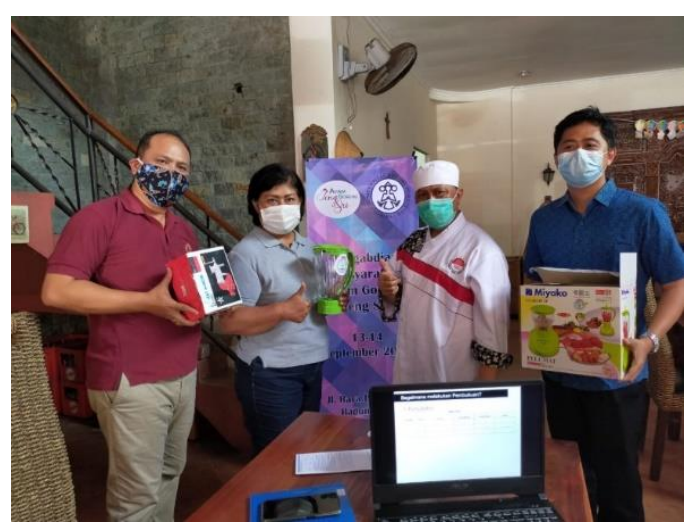

Gambar 1.4. Pelatihan Teknologi tepat guna dan Manajemen

4. Kegiatan pelatihan pemasaran. Dalam meningkatkan omzet penjualan, maka diperlukan pelatihan tentang pemasaran melalui internet, media cetak, media social (FB, IG, Line) dan memasukan Ayam Goreng ke sistem aplikasi Go Jek dan Grab. Disamping itu juga menyediakan fasilitas Wifi di warung tersebut. Semakin banyak promosi, maka masyarakat banyak yang mengkonsumsi Ayam Goreng Jeng Sri tersebut.

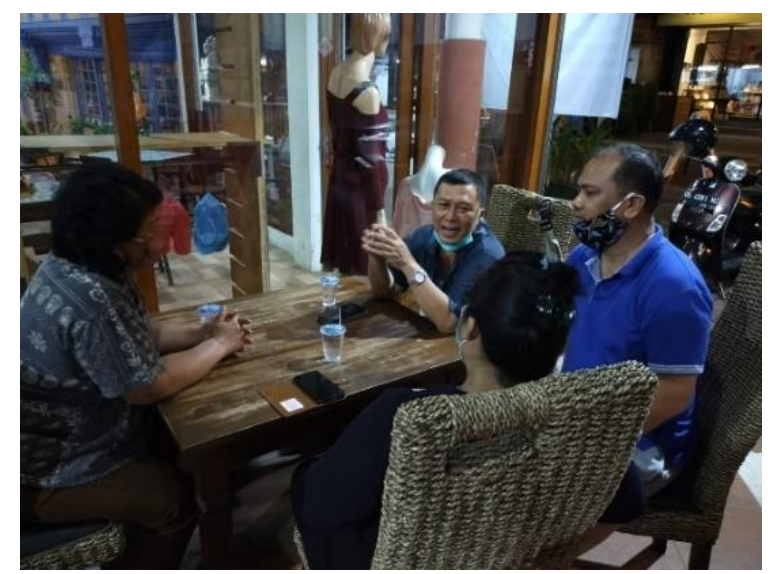

Gambar 1.5 Pelatihan Manajemen Keuangan dan Pemasaran

Di bawah ini adalah grafik 1 yang menunjukan pelatihan kepada mitra sebelum (Warna biru) da sesudah (warna orange) pelatihan dengan ketiga permasalahan mitra yaitu tentang produksi, Teknologi pemasaran dan manajemen keuangan. 


\section{Grafik 1 Outcome Pelatihan ketiga permasalahan Mitra (produksi, teknologi \\ pemasaran dan manajemen keuangan}

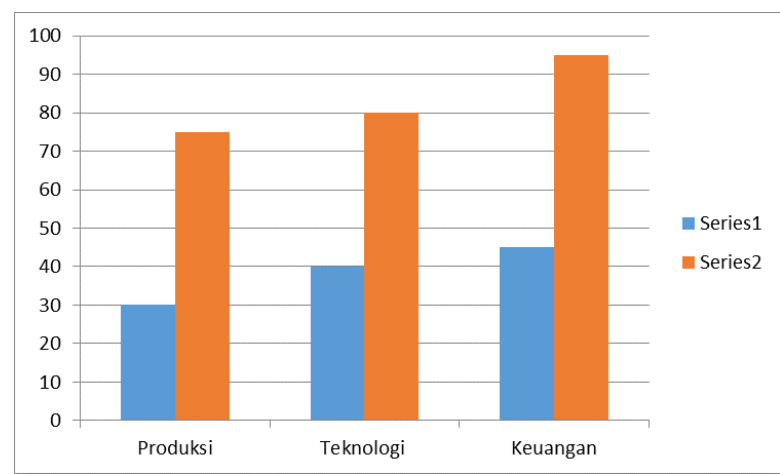

\subsection{Partisipasi dan kontribusi mitra}

Setiap kelompok usaha Ayam Goreng Jeng Sri berpartisipasi dalam menyiapkan tempat untuk kegiatan sosialisasi maupun pelatihan program ini. Selain itu, selama sosialisasi dan pelatihan berlangsung konsumsi disediakan oleh kelompok mitra sebagai bentuk kontribusi nyata bahwa program ini sangat mereka butuhkan untuk meningkatkan produktivitas dan omzet penjualan.

\subsection{Rancangan evaluasi}

Dalam rangka mengevaluasi PKM ini, maka anggota kelompok harus melaksanakan setiap petunjuk yang telah diberikan oleh para pakar secara konsisten. Tim akan melakukan supervisi dan monitoring (Tes diawal dan tes akhir untuk mengetahui pengetahuan mitra) ke lokasi secara berkala, sehingga dapat diketahui perkembangan usaha Ayam Goreng, Jeng Sri tersebut.

\subsection{Keberlanjutan program}

Dalam rangka keberlanjutan program ini maka setiap kelompok usaha mitra ini terus meningkatkan produktivitasnya serta mengajar kelompok usaha yang sejenis atau pun berbeda agar mendapatkan pengetahuan dalam mengelola usahanya secara profesional. Dengan demikian, program ini dapat menciptakan lebih banyak wirausaha baru di desa ini secara khusus dan wilayah Bali secara keseluruhan.

\section{Simpulan}

Dalam menyelesaikan masalah di atas, maka solusinya adalah memberikan pendampingan, penyuluhan, dan pelatihan tentang menajemen pengelolaan dan pemasaran, penggunaan teknologi, laporan keuangan serta diversifikasi produk seperti membuat pentol Bakso, Mie Ayam dan Pork Baley. Target program ini bersifat aktual untuk meningkatkan pengetahuan dan wawasan kelompok usaha Ayam Goreng, Jeng Sri semakin lebih baik.

\section{Ucapan Terimakasih}

Trimakasih kepada LPPM Universitas Dhyana Pura yang telah mendanai pengabdian kami tahun 2020.

\section{DAFTAR PUSTAKA}

Andimarjoko, P. dan Wiharto, B. 2014. The effects and importance of authenticity: A studi on Indonesian and Thai restaurant in Prague. Dalam Jurnal of Business and Entrepreneurship. 2 (3): 36-52.

Atmanto, A.M. 2014. Efektifitas iklan pada situs jejaring sosial (sebuah studi pada situs facebook.com). Dalam Jurnal of Business and Entrepreneurship. 2 (3): 17-35.

Atmoko, W.B. dan Among, N. 2016. Sustainability consumption: Perubahan perilaku mengkonsumsi daging. Dalam Jurnal Ekonomi dan Bisnis. XIX (2): hlm. 249-267.

Djumaty, B.L. 2015. Dari "ya" menjadi "tidak" studi tentang persepsi dan sikap masyarakat Desa Idamdehe terhadap rencana pembangunan PLTP di Idamdehe dan Idamdehe Gamsungi. Dalam Jurnal Studi Pembangunan Interdisiplin "Kritis". XXIV (1): hlm. 21-39.

Gunawan, K.Y.I. dan Suprapti, N.W.S. 2015. Peran pendapatan dalam memoderasi pengaruh sikap pada kesediaan membayar produk ramah lingkungan. Dalam Jurnal Manajemen, Strategi Bisnis dan Kewirausahaan. 9 (1): hlm. 74-82.

Hapsari, R.D. dan Prakoso, I. 2016. Penanaman modal dan pertumbuhan ekonomi tingkat provinsi di Indonesia. Dalam Jurnal Ekonomi dan Bisnis. XIX (2): 210-227.

Leovani, E. 2016. Implementasi modal pemberdayaan karyawan (Employee empowerment di PT FIFGROUP Tbk cabang Palembang). Dalam Jurnal Manajemen. XX (1): hlm. 241-259.

Primayani, P.M. dan Reonningrat, N.L.P.A. 2015. Analisis kualitas pelayanan terhadap kepuasan pelanggan di PDAM Buleleng 
cabang Kubutambahan. Dalam Jurnal Manajemen dan Akuntansi STIE Triatma Mulya. 21 (2): hlm. 157-168.

Wijayanti, A.W. dan Insani, S.F. 2016. Analisis anteseden kewirausahaan di perusahaan keluarga. Dalam Jurnal Ekonomi dan Bisnis. XIX (2): hlm. 290-306.

\section{Lampiran 3. Gambaran Ipteks yang Akan Ditransfer Kepada Mitra}

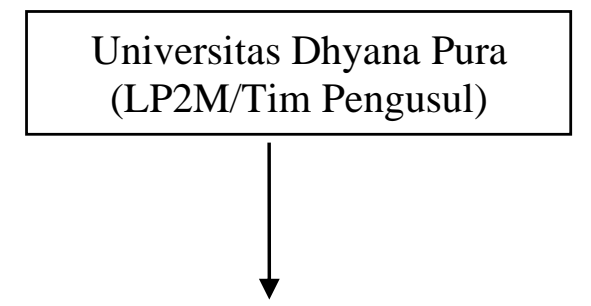

Mitra Ayam Goreng, Jeng Sri kelompok Ni Wayan Sri Wahyuningsih di Desa Plaza, Kabupatern Badung

Masalah:

1. Minimnya penggunaan teknologi tepat guna dalam proses produksi.

2. Kurangnya pemahaman etika dan budaya.

3. Kurangnya pemahaman tentang manajemen.

4. Kurangnya pemasaran produk.

Solusi:

1. Pendampingan dan penyuluhan tentang penggunaan teknologi tepat guna.

2. Peningkatan pelayanan sesuai etika dan budaya konsumen.

3. Peningkatan manajemen pengelolaan dan penggunaan computer dalam pembuatan laporan keuangan.

4. Peningkatan pemasaran melalui internet.

Target dan keberlanjutan program:

1. Memberikan kepuasan kepada konsumen sehingga semakin suka ayam goreng

2. Meningkatkan pendapatan kelompok mitra usaha ayam goreng.

3. Meningkatkan kesejahteraan masyarakat sekitar.

4. Membuka kesempatan bagi wirausaha baru.
Lampiran 4. Peta Lokasi Wilayah PKM Usaha Ayam Goreng Jeng Sri

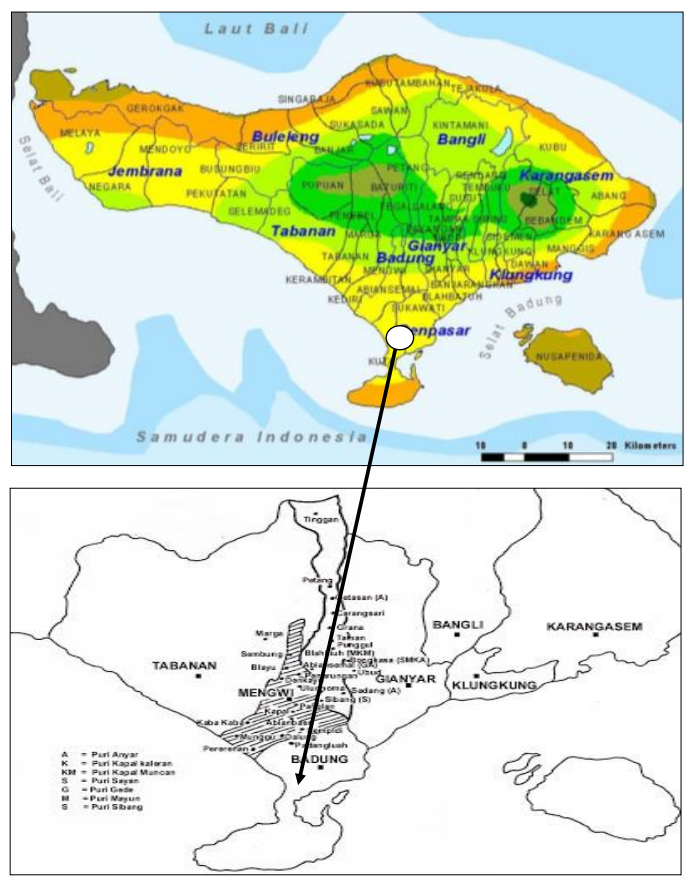

Lokasi PKM Usaha Ayam Goreng, Jeng Sri di Desa Kerobokan, Kecamatan Kuta, Kabupaten Badung, Provinsi Bali

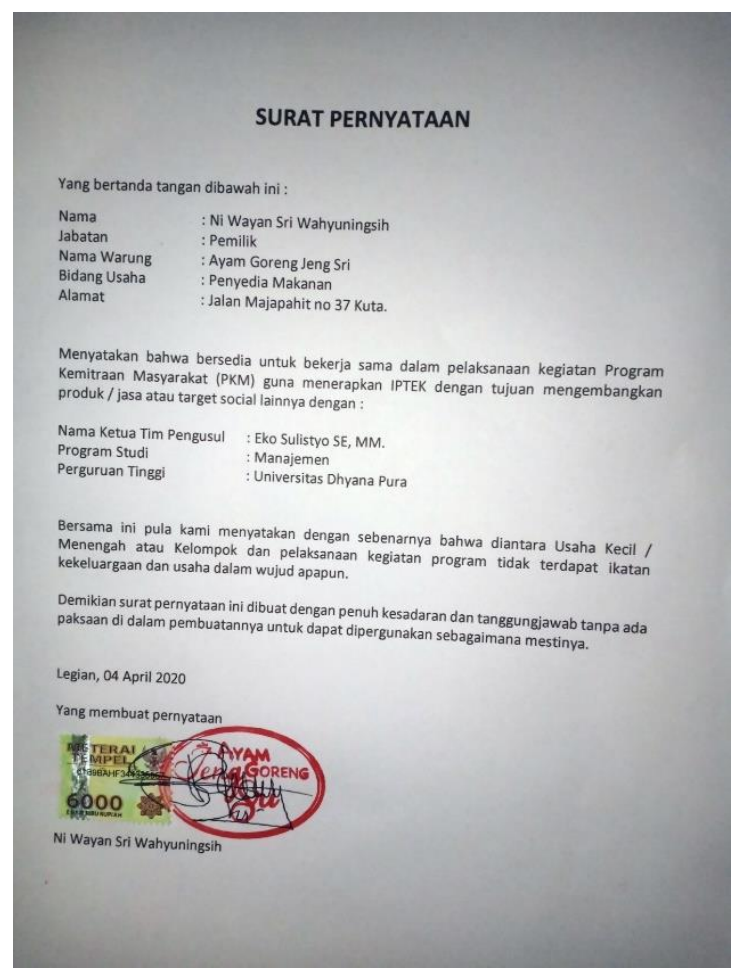

